\title{
The theology and praxis of practical theology in the context of the Faculty of Theology
}

\begin{abstract}
Authors:
Tobias H. Steyn ${ }^{1}$

Maake J. Masango ${ }^{1}$

Affiliations:

${ }^{1}$ Department of Practical

Theology, University of

Pretoria, South Africa

Correspondence to:

Maake Masango

Email:

maake.masango@up.ac.za

Postal address:

PO Box 84173, Greenside

2034, South Africa

Dates:

Received: 09 Sept. 2010

Accepted: 14 Aug. 2011

Published: 15 Nov. 2011

How to cite this article:

Steyn, T.H. \& Masango, M.J.

2011, 'The theology and

praxis of practical theology

in the context of the Faculty

of Theology', HTS Teologiese

Studies/Theological Studies

67(2), Art. \#956, 7 pages.

http://dx.doi.org/10.4102/

hts.v67i2.956
\end{abstract}

C 2011. The Authors.

Licensee: AOSIS

OpenJournals. This work

is licensed under the

Creative Commons

Attribution License.
Notwithstanding the carefully defined parameters of the various departments within theology, the aspirant student sometimes finds it difficult to define the precise department within which a specific study would best be located. We have discovered that these various fields and departments have many areas of commonality and the borders between them are tested often, even in our own studies. However, we have learned that crossing between one field and another should not be seen as a problem but as strength, as it will enable the researcher to motivate and test his or her theological convictions. It is in this context that the subject of this article finds its motivation. Through it we have argued for a practical theology that will be responsible for engaging with its own theology, in order to find the necessary energy to sustain itself. Not only should practical theology be energised by its theology, it should also, as its name implies, be practical in its nature, offering help to all people in need of pastoral care.

\section{Introduction}

The study of science, calculus and perhaps engineering is conducted within the parameters of an external world, whereas the study of God, through theology, is conducted within the confines of the persons' own self. As we journey through the pages of our theological studies, we continue to discover deeper within ourselves who and what we really are. Over many years, the science of the study of theology developed into many different faculties, departments and fields of specialties. This took place because, through theological studies, many students and researchers became experts in their specific field of study, which originated from their focus on a specific department within the Faculty of Theology. In this process, the study of the theory and praxis of theology moved to higher levels as individuals lifted the standard of their education, also helping others to reach a higher understanding of God. In this process, many theologians attained very high levels of education and specialty. One could argue that these high levels of education and specialties have lifted the standard of care offered to people in need and, indeed, many would not dare to prove the opposite.

However, we find this phenomenon of a fragmented faculty rather problematic, because theology has became fragmented to a point where theologians each aggressively protect their own specific area of specialty. Students are continuously cautioned not to overstep their area of study and research and, as such, they are often restricted to the boundaries of their specific theology department. This fragmentation has impoverished the richness and the holistic nature of theology because it limits its ability to affect the whole person, both the researched and researcher.

In the context of the above, the reader needs to understand that we are very aware that the boundaries between the various theological departments serve a good purpose, heightening the level in which we engage in theology. Yet, as theologians in the Department of Practical Theology, we argue for a theology that will often test the boundaries of practical theology. Hence, for the purposes of this article, we will speak to the confined area of practical theology and its need to dwell in departments outside of its traditional parameters. The reader should also understand that we are not opposing other departments within theology; rather, we argue for a broadening of the practical theology student's horizons.

Nevertheless, one could challenge our argument by asking why it is necessary to dwell in areas that are researched by other departments? Our presumptive answer would be to say that this broadening is necessary in order to provide a heightened energy for a sustained praxis of practical theology itself. However, without providing sound theological reasoning to substantiate this notion, it runs the danger of becoming an over-generalisation that will not help the aspirant student; hence the generation of this article. 


\section{Practical theology: More than just praxis}

Many theologians would define study or research in practical theology primarily as procedural, as they consider this theological department only to be involved in the practical outworking of one's theology. Yet, through our personal research in practical theology, we came face to face with many more questions that we could not answer if operating only within parameters of the above definition. Gerkin (1986) argues for a practical theology that will also interpret, understanding that:

... pastors and pastoral care theorists must constantly have one ear open to the shifts that take place in the ways persons experience their needs and problems of living and the other open to the currents of change in ways of understanding and interpreting human needs.

(Gerkin 1986:12)

Practical theology should meet the praxis of pastoral care for the people it seeks to serve as it 'interprets human needs'. This understanding and interpretation of human needs points to a theological and hermeneutical analysis of a practicalpastoral problem. In this context, we mean that pastoral problems cannot be separated from their urge to caregivers to find solutions in the praxis of the same. Furthermore, this understanding and interpretation should also provide the caregiver with the motivational means to offer this pastoral care from within his or her theological convictions. To say one should care for those in need in a pastoral way and yet not grapple with the question of why one should care at all would be somewhat presumptuous. Practical theology should therefore both prompt and sustain the following question: what is the motivation for this conviction to care?

Don Browning, the Alexander Campbell Professor of Religion and Psychological studies at the Divinity School of the University of Chicago, also shares this sentiment when he writes:

... practical theology must be more than methodological; it must actually do theology and it should do it in such a way as to illuminate Christian practice in religion to life's concrete problems and issues.

(Browning 1985:15)

When practical theology becomes so narrow that it only depends on the praxis of theology, how could the student motivate the 'who's', 'where's' and 'when's' of his or her research? Unless the praxis of theology is motivated from within that researched theological self, it would need to find its motivation for being practical from another source. From Gerkin (1986:18) we understand and agree that 'theology is central to all forms of ministry'. Unless practical theology is building upon actual theology, it will become a fragmented theology, because it would not be able to motivate theologically that which it is asking its practitioners to do. This dependence upon other sources will weaken practical theology, turning it into a mere practical outcome of someone else's theological convictions. That is why we hold that, unless practical theology actually engages in theology itself, it will become an unbalanced field of study where students would need to act in a conceited way. The conviction that Christians should care in a practical and pastoral manner is plainly not good enough. This pastoral care should find its motivation from within the caregiver's theological convictions, in order to find sufficient energy to sustain the care that is offered.

\section{Theological convictions motivate theology in praxis}

As practical theologians, we are deeply concerned that students' theological convictions should create a theology in praxis. Pieterse (2001:9) shares this sentiment as he believes practical theology to be a study of Christian actions. This helps to establish an understanding that practical theology cannot be separated from its praxis, which, in turn, cannot be separated from students' own theological convictions. It is traditionally acknowledged that William Booth, founder of the Salvation Army, defined evangelism as 'one beggar, telling another beggar where to find bread'. From the above definition one could be forgiven for seeking an understanding of practical theology. In the same context, Campbell (1987:188) is helpful with his understanding that practical theology is concerned for the well-being of people in communities. Hence, practical theology could not be a one-sided theology, where one party becomes the giver and the other the receiver. Through practical theology, we, as giver and receiver, researcher and researched, student and teacher, become companions on the road to getting to know God better and this could only be achieved in a practical way.

Patton (1993:238) wrote that practical theology involves a 'two-way movement between theory and practice'. From this context, it becomes evident that Patton, as well as Browning (1985:16), sees practical theology mainly as a 'practical theology of care'. Not only is this theology practical in its care, we want to urge that this theology should also find its praxis in the area of the public domain. Browning (1985) also dwells on this when he states that the practical theologian should communicate to the church, but also to those outside of the church:

What we call pastoral care should be reconceived as a practical theology of care and should address not only the pastoral care of those within the church but an attempt to both criticize and fulfil the care structures of the larger society. Similar statements could be advanced for the other regions of practical theology-ethics, worship, and preaching. Both the inner-ecclesial and public foci of these activities would be part of the concerns of practical theology.

(Browning 1985:16)

This quotation quickens the concept that practical theology falls within the arena of theology, yet it positions theology in a practical way to those in the church, as well as to those not within the defined structures of church. The church's theological conviction will explain and motivate its praxis of faith lived out from day to day. Only once practical theology becomes critical in its theological analyses of what is happening in our communities, can it assist Christians to motivate positively their engagement in pastoral care. 
Hence, through philosophical and critical analyses of what is happening in communities, practical theology will not only motivate faith communities to offer pastoral care, but will also assist in creating models or praxes of this care. In addition, because these praxes would be motivated from within a wellformulated theology, they will become sustained by their existence, because faith leads to action.

This understanding poses a major challenge to students of practical theology. How can students motivate people both inside and outside the church in a theological way to care pastorally for their neighbours in need, unless this motivation is also accompanied with a practical model on how best to demonstrate this care? Until practical theology urges its students to dwell in the arena of actual theology, this question will remain unanswered.

\section{Practical theology: A means of practical interpretation of theological convictions}

Aden and Ellens (1988) ask whether one could separate the notion of being part of the church from that of offering pastoral care; could one claim to be part of the church and its faith traditions, yet turn one's back upon pastoral care towards people? By merely being part of the church and its faith tradition, the believer, to a more or lesser extent, interprets his or her own theological convictions. The important question in practical theology is whether this interpretation brings the believer to a point of offering pastoral care. Aden and Ellens (1988:36) argue that the practice of offering pastoral care is the formal expression of the Gospel of Jesus Christ and they challenge their readers to ask themselves:

So what is the status and role of pastoral care in the church? Is it an essential form of Christian ministry, or is it a secondary function that is important only if it fulfils the primary task of proclaiming the Word? We will answer that question only as we clarify pastoral care's relation to the gospel that is only as we clarify what pastoral care is.

(Aden \& Ellens 1988:34)

Here Aden and Ellens are saying that one can hardly separate theology and its praxis, because this theology in practice 'fulfils the primary task of proclaiming the Word'. Browning (1985) defines this even further by saying that practical theology is more than just theology of praxis in pastoral care. This theology should interpret ethical and moral issues, in order for it to motivate theologically the praxis of the pastoral care offered:

In this perspective, the interpretative interests of hermeneutics are not ends in themselves but processes of understanding and self-interpretation toward the goal of orienting individuals and communities toward action. Practical theology, to be practical, must attempt to describe and interpret both contemporary situations and classic Christian resources.

(Browning 198516)

In this, Browning understands that through a hermeneutical approach to practical theology, one could motivate the church and societies around it towards action. The reader should realise that the goal of this approach is not to attain a deeper understanding of the problem through hermeneutical analyses, but to use this deeper understanding to motivate people for action in the praxis of pastoral care towards the church in need. In this context, Oglesby (1986:125) argues that 'well equipped clergy' should enable the people of God to function more effectively in their care towards other people of God, whilst in the Book of James it states that faith without action is dead (Ja 2:26). Both of these are well-known concepts within Christian communities and we claim no originality in these notions. However, could this mean that the other side of this implies that action cannot be motivated outside faith? Hence, unless Christians reach a place where their faith motivates them into action, the praxis of their pastoral care will not be enacted; or rather, will not happen on the level it should. From the above, we feel the urgency in returning to the notion that people's theological convictions will encourage them into care for others in a pastoral manner because practical theology cannot be separated from a praxis that is motivated from within its theological convictions. This care, however, also cannot be separated from the context of the people it seeks to help.

\section{Practical theology in the context of the people it seeks to help}

De Gruchy (1986:8) helps us understand that practical theology will always be set within the specific context of the caregiver and the care-seeker. Adding to this notion, Parrat (2004:2) stresses that this context is birthed from within the history of both the theologian as help-giver and in the history of the help-seeker. This means that the value and manner of the praxis of the care offered will be different according to the paradigm of both the caregiver and care-receiver. Hence, action, which has great value for the caregiver does not necessarily have great value, or any value for that matter, for the care-receiver - and the opposite is true as well. This sometimes becomes a problem for caregivers, because the care they offer very often comes at a great cost to themselves, yet this sacrificial aid is often not appreciated by care-seekers. Bonino (2004:131) furthers this argument by stressing that people cannot be freed of this context of self and of the people they seek to help. From this, one can understand that the context of theology in practice, both offered and received, becomes a critical element in making this theology beneficial for both the caregiver and care-receiver.

In this same notion, Lartey (1997) proposes that:

There are significant ways in which the concerns of liberation theologians and pastoral carers can be served by a greater degree of attention to who the readers are, how they read the texts and what they do with them.

(Lartey 1997:99)

Here Lartey urges caregivers to be mindful of the context of people who need care. Unless the practical theologian explicitly takes care to be mindful of both the context of those in need of care and the context of those offering help, this help runs the risk of being of very little value. Clinebell (1984:14) 
challenges this even further as he dares to say that theology outside of its context becomes irrelevant. Hence, although practical theology seeks to be practical in bringing theology to people, one should not lose sight of the fact that this help should be given within the context of the people it seeks to liberate. Being theologically correct, praxis will be of no value unless it is liberating within the paradigm of the people it seeks to help. Nevertheless, Msomi (1993:75) is critical of this point when he speaks out against Western-based care without considering the context of local people in Africa. That which Westerners see as loving care often becomes offensive to the recipients of this care in Africa. The reader can understand that this well-intended care often becomes a point of conflict between the caregiver and care-receiver. Browning (1985) emphasises this strongly as he writes:

For practical theology to be genuinely practical, it must have some description of the present situation, some critical theory about the ideal situation, and some understanding of the processes, spiritual forces, and technologies required to get from where we are to the future ideal, no matter how fragmentarily and incomplete that ideal can be realized.

(Browning 1985:20)

From the above we wish to urge practical theologians firstly to familiarise themselves with the current situation of the care-seeker before he or she evaluates what is wrong with the situation, if anything is wrong at all. Only then can the caregiver create a theology motivating the praxis of pastoral care that is needed within the context of the care-seeker.

\section{Pastoral care in the framework of practical theology}

David Tracy's (1983:76) attempt to define practical theology is of great help in enabling us to understand that one should make a connection between the theory of practical theology and the praxis of the same. He states that: '... practical theology is the mutually critical correlation of the interpreted theory and praxis of the Christian faith and the interpreted theory and praxis of the contemporary situation.'

Both theory and praxis are essential elements and together they form the real meaning of practical theology; anyone attempting to apply the one without the other will find it very difficult to motivate why the praxis of the needed care is so critical. At this point, we believe it is necessary to emphasise our convictions that practical theology will find the energy to sustain itself from within the philosophy of the theological self. However, we are very aware that one should strive to balance the theory and the praxis of practical theology because this theory becomes the vehicle and motivation for taking one into the praxis of practical theology.

The reader can appreciate that as practical theologians, we are aware that the theology we hold manifests itself in praxis in the form of the pastoral care we offer to those in need. Gerkin (1997) is helpful to define pastoral care within the framework of practical theology through the story of his call to serve in a congregation. Shortly after his arrival in that congregation, a woman phoned him to ask whether he would conduct a certain task, because the previous minister had always done it. He refused and asked whether they could not do it themselves, for, as Gerkin (1997:118) writes: 'I was not going to be the one who ran churchly errands or did things for them or their children that they could do for themselves'. With this, Gerkin challenges his readers to understand that true pastoral care cannot be the 'easy way out'. Sometimes we need to act speedily - occasionally we need act over time - and then, again, at times we need to abstain from any action. All these instances should be seen as pastoral care. Yet, the latter will often prove to be the more difficult course, because true pastoral care originates in something much deeper than mere action or non-action. In offering pastoral care to people, one continuously needs to ask the question: how can I care for people in such a way that they will be able not only care for themselves but begin to care for others who are also in need?

Solomon (1992:137) shines more light on this understanding when he says that true pastoral care for people in need will bring them to a place where they can enter into communion with God. Our Christian caring is based on Jesus Christ being the 'I AM'. Jesus not only spoke the word of God, he is the very Word of God, he is the Truth, he is the Way and he is the Life. If this is then our true conviction, pastoral care is far more than a mere theoretically motivated praxis. Again, Getz (1986) expanded on this notion when he looked at it from a different angle, saying that Christians should never permit themselves to care pastorally for others in difficulty if their motives for doing so can be questioned:

Paul made this point before he challenged these believers to follow Christ's example. Your 'encouragement', he wrote, should come 'from being united with Christ'. When we were without hope in this world, Christ made it possible for us to have hope. Moreover, that hope came into our lives because of Christ's servant heart towards us. Therefore, our motivation to serve others should come because of God's marvelous grace toward us when we were undeserving sinners. When we are tempted to be selfish and proud, we need to think of what Christ did for us.

(Getz 1986:128)

With these words, Getz challenges his readers to ensure that any care offered is not aggravated by any wrong motives. The only reason why Christians should care for people in need originates in the hope Christians have in Christ, built upon God's grace for humankind. Because God cares for humankind, humans are able to care for other humans 'because we are held in God's memory' (Patton 1993:15). Christian care offered as the result of any other motivation, such as for political or financial reasons, will become something lesser than that which God intended it to be.

\section{Obstacles in the praxis of practical theology}

'Ascetic Christianity called the world evil and left it. Humanity is waiting for a revolutionary Christianity, which will call the world evil and change it' (ed. Bauckham 1999:77). 
A wise man and friend once confronted me in saying that 'one can stand on the sideline and blame the world for all that is wrong, or you can get inside the world and change things for the better'. In doing this, the church will become God's prophetic voice to the world around it. God called the church to be the head and not the tail, in order to influence the people around it with the truth and love of God (see Dt 28:13).

Furthermore, we hold that to speak of the theological motivation to care without including the practical outcomes of this motive within the context of practical theology would fall short of what we intend to illustrate in this article. The kind of practical theology we believe will give theologians the vehicle both to motivate pastoral care for a people in need from within its own theological convictions and also to work towards a praxis for offering this pastoral care. This all should happen to best of the theologian's ability, within the context of self and the people for whom it seeks to care. The above notion might sound very noble, but time has proved that it is a mammoth task given to caregivers.

The largest contingent of the church will agree that Christians need to care for those people in need, yet this necessary care very often does not happen. We believe that most pastors and ministers in various congregations and denominations would agree when we say that it is very difficult to cultivate a caring community within the ethos of the church. Within this context, Tillich (2000) strongly argues that:

We work hard and play hard not because we are more industrious or more playful than our ancestors are but because we dare not stop lest in the stillness we are overwhelmed by the sound of our own anxieties and fears.

(Tillich 2000:xvii)

Here Tillich challenges the business of the modern lifestyles to which most people become so accustomed, as this business becomes a smokescreen to hide our own inabilities, or unwillingness to care. Could this mean that people, including ourselves, are so guilty of the same kind of offences, injustices and pain we see around us that we dare not speak out for fear that we would be caught out with our own words? We work hard, we play hard and behind this business, we hide our own brokenness, because we have no idea how to deal with our own pain, let alone the pain and suffering of the people around us. This notion causes many caregivers to shy away from the purpose of practical theology, that is, to offer practical pastoral care to those in needs.

The problem with this attitude is that, when ignoring our neighbours in need, it becomes inescapable that people will ignore God's call and purpose for their own existence. The implication of this insubordination will have extensive effects, as Bonhoeffer (2003:21) succinctly notes: 'Only the obedient believe. If we are to believe, we must obey a concrete command'. This is similar to the saying that 'The things we do, are the things we believe, the rest is just religious talk'. Indeed, on hearing this for the first time, one could be offended by its suggestion, for how could it be that the church's faith could be measured by its level of obedience to act? Is it not by faith alone that people can be saved?

Again, the thought that 'faith alone' can save posed a huge challenge for us, one which the reader needs to understand from the context in which we question this dogma. In James 2:14 the 'faith alone' belief is also challenged, as this passage questions whether 'such faith' can indeed save. At this point one needs to ask what kind of faith the Book of James urges from its reader. Could the author of the Book of James suggest that the fruit, or outworkings of faith, becomes theology in action? If this is true, then one should be able to measure faith through the praxis of practical theology.

In this context, praxis means action and not a theoretical willingness or conviction, where this action is motivated from within a theological confidence that comes from obedience to the call of God. From this notion, we profess that the word 'obedience' does not share the same meaning as the word 'willingness'. Jesus was not willing to die on the cross, because he called upon his Father to remove this cup from him (Lk 22:42). Yet, he chose to obey his Father and died upon that cross. From this, we learn that Jesus' obedience did not come from his willingness to die on the cross; Jesus' obedience was an act of his will. Bonhoeffer (2003:35) expands of this notion: 'When he was challenged by Jesus to accept a life of voluntary poverty, the rich young man knew he was faced with the simple alternative of obedience or disobedience.' To obey or to disobey is a choice Christians makes daily, where obedience can only follow a command. Could this suggest that the praxis of practical theology will often manifest not from willingness, but from obedience of the caregiver? If Jesus did not call the rich young man to voluntary poverty, obedience would not have been possible as there was nothing to obey. Because of his choice of non-obedience, this young man was disqualified from entering into the Kingdom of Heaven (Mt 19:23). God called his people to care for their neighbours. This brings us to the point of making a choice: will we obey God's call, or will we ignore our neighbour in need of care? In this context, it seems that the Christian has no luxury of another choice; they can only obey or disobey.

Yet, it is not as simple as pure obedience or not. So often we discover a community that cares, but one in which this care is confined to set parameters. This selective way of caring is not a modern occurrence. An expert in Jewish law tested Jesus with a similar question: 'And who is my neighbour?' (Lk 10:29). The Scripture states that he wanted to 'justify himself' and his actions through this question. Today, we may ask why he would want to do this? From this context, it seems this expert in Jewish law attempted to justify his lack of love towards people he did not recognise as his neighbour. It is not at all difficult to love the loveable people in our lives; however, it is tougher to express love towards those whom we do not want to love. In response to the expert's question, Jesus told a story that later became known as the parable of the Good Samaritan. This allegory is still popular in motivating our understanding of who qualifies to be our 
neighbour. Who is the one that will be on the receiving end of our Christian care? To this end, Wise (1989:4) shows great insight when he states: 'If our concern to help ends with those who require little cost on our part, then we will not help many.'

\section{Practical theology and its praxis in the context of poverty}

There is a confidence amongst many theologians that God favours the poor. This theological conviction largely influences their motivation and the methodology in the praxis of care they offer to people in need. Indeed, it seems that these theologians find their motivation for care from within their sympathy towards the politically oppressed, who are also most often the financially deprived. Buffel (2007) states his convictions blatantly as he writes:

Just as God favours the poor, the church must do the same. Jesus Christ furthered this preferential option for the poor, the oppressed and the marginalized in his statements and his ministry.

(Buffel 2007:52)

We find that this notion seriously confronts our understanding of God's love, as it compartmentalises his unlimited love for all people (cf. Jn 3:16). How could one categorise God's love and favour in this manner? Could this imply that poor people find salvation in Christ more easily that their richer fellow humans? Does this mean that poor people have a greater share in the salvation only Christ can offer? This theological basis for God's favouritism is very dangerous, because if God favours the poor, it unavoidably means that God is 'disfavourable' towards the rich.

At this point we are very aware of Jesus' words about the rich young man (see Mt 19:23). It would prove to be very difficult for the rich to enter into God's Kingdom; however, does this really mean that God is more favourable towards the poor? The reason why we find this theological conviction so difficult to accept is rooted in Jesus' concern for all people. In this, we are saying that God does not make it more difficult for the rich to enter his Kingdom, nor does he lower the standards for the poor. We find confidence in this notion as Zacchaeus, a rich tax collector, found favour with Jesus, who said: 'Today salvation has come to this house, because this man, too, is a son of Abraham' (Lk 19:9). God does not favour of one human being above another and the Bible explicitly states this (see Ac 10:34; Rm 2:11). In John 3:16, Jesus expressed God's love for the world, rich and poor alike. Davids strengthens this notion when he writes:

When we understand that God wills the salvation, development and progress of all His creation, it gives us the impetus to look at any context as a context in need of God's redemptive presence, not because we are scared or need security, but because God wills it.

(ed. De Beer 2002:33)

However, the reader should take note that we are deeply convinced that God is not favourable towards the injustices that cause people to be poor. I have confidence that God will oppose the acts of people who oppress others financially, politically, or any other way. Within this context, we urge the reader not to be caught in the trap of an, 'us' and 'them' situation, where the 'us' are the oppressed and 'them' the oppressor, or where 'us' are the poor and righteous and 'them' the rich and wicked. We wish to sound a warning in saying that this is a very dangerous game to play. Rich and poor, good and bad, high and low, fat and thin: these are all very relative concepts and extremely difficult to qualify, unless one can measure it against a set standard. In this instance of human standards for righteousness and evil, it becomes an even greater problem, because believers are not measured against one another. Our holiness, wickedness, righteousness, riches or poverty is not measured against our fellow human standards, because there is a much higher standard for measurement. God called believers to be holy, righteous and rich according to his standard (Lv 11:44) and all human beings have fallen short of this glory of God (Rm 3:23). In fact, we all are human and in desperate need of God's grace, whether we are rich or poor, Christian or pagan. No one who is human can say that God favours me, us, him or her above another human being. All people are in desperate need of God's grace. This theological conviction has become the sustained energy in our personal journeys, searching for meaning to life through theological studies. Our deeply rooted convictions that God is intensely concerned about our individual existence have enabled each of us to be concerned about the existence of the people around us. We can love, because God first loved us as individuals (see 1 Jn 4:19). Heschel (1975) agrees with this notion as he writes:

Neither prediction nor speaking in the name of God is the most important feature of biblical prophecy. The prophet is not sent to the people in order to demand that some particular act be done; he is sent because of a divine concern for the total existence of the people.

(Heschel 1975:251)

\section{Conclusion}

This article urges the practical theologian to wrestle with theology, in order to motivate the praxis of practical theology. We motivated this notion from our conviction that the praxis of theology can only be sustained over prolonged timeframes once the caregiver is theologically convinced of the need to care for those in need. Hence, unless the caregiver has the conviction to care through his or her theology of care, this praxis of care will not be sustained.

Being practical in nature, practical theology cannot be freed from its praxis. In this we are saying that practical theology, although motivated through theological convictions, cannot be separated from its practical outworking of the faith it professes. The practical theologian cannot separate themselves from those in need, as Gerkin (1986) agrees:

Practical theology always takes place in the midst of praxis and is prompted by the situation of 'being in the midst' ... In that sense practical theology is always, or virtually always, done 'on the run', so to speak, or in the midst of the necessity of action.

(Gerkin 1986:60) 
In this same context, Campbell (1981:82) understands that people become companions on the same journey as they pastorally care for one another. Our neighbour is the one who makes this journey with us. As travelling companions, the caregiver and care-receiver will gain authority to become friends and comrades on this journey of pastoral care as they engage in the practice of practical theology.

\section{Acknowledgements Competing interests}

The authors declare that they have no financial or personal relationship(s) which may have inappropriately influenced them in writing this article.'

\section{Authors' contributions}

This article is an adaptation of T.H.S.'s doctoral thesis within the Department of Practical Theology at the University of Pretoria, as supervised by M.J.M.

\section{References}

Aarflot, A., 1988, Let the Church be church - The voice and mission of the people of God, Augsburg Publishing House, Minneapolis, MN.

Aden, L. \& Ellens C., 1988, The church and pastoral care, Baker Book House, Grand Rapids, MI.

Bauckham, R. (ed.), 1999, God will be all in all, T \& T Clark, Edinburgh.

Bilezikian, G., 1997, Reclaiming the local church as community of oneness, Zondervan Publishing House, Grand Rapids, MI.

Bonhoeffer, D., 2003, The cost of discipleship, SCM Press, Canterbury.

Bonino, M., 2004, An introduction to Third World theologies, Cambridge University Press, Cambridge.

Browning, D.S., 1985, 'Practical theology and political theology', Theology Today 42, 15-33. http://dx.doi.org/10.1177/004057368504200104

Buffel, O.A., 2007, 'Pastoral care in a context of poverty: A search for a pastoral care model that is contextual and liberating', Doctor of Sacred Theology dissertation, Faculty of Theology, Drew University.

Burger, C., 1991, Praktiese Theology in Suid-Afrika, RGN Uitgewery, Pretoria.

Campbell, A.V., 1981, Rediscovering pastoral care, Darton, Longman and Todd, London.

Campbell, A.V. (ed.), 1987, A dictionary of pastoral care, SPCK, London.

Capps, D., 1984, Pastoral care and hermeneutics, Fortress Press, Philadelphia, PA.

Clinebell, H., 1984, Basic types of pastoral care and counselling, Abington Press, Nashville, TN.
Cochrane, J., De Gruchy, J. \& Petersen, R., 1991, In word and deed - Towards a practical theology of social transformation, Cluster Publications, Pietermaritzburg.

De Beer, S. (ed.), 2002, Hidden treasure, Pretoria Community Ministries, Pretoria.

De Gruchy, J.W., 1984, Bonhoeffer and South Africa. Theology in dialogue, William B. Eerdmans Publishing Company, Grand Rapids, MI.

Dever, M. \& Alexander, P., 2005, The deliberate church, Crossway Books, Wheaton, IL. Farmer, J.T., 1993, Ministry in community - Rahner's vision of ministry, Peters Press, Oakland, CA.

Fowler, J.W., 1981, Stages of faith - The psychology of human development and the quest for meaning, Harper \& Row, San Francisco, CA.

Frankl, V.E., 1946, Man's search for meaning, Square Press, Washington, DC.

Gerkin, C.V., 1986, Widening the horizons: Pastoral responses to a fragmented society, The Westminster Press, Philadelphia, PA.

Gerkin, C.V., 1991, Prophetic pastoral practice, Abingdon Press, Nashville, TN.

Gerkin, C.V., 1997, An introduction to pastoral care, Abingdon Press, Nashville, TN.

Getz, A.G., 1986, Serving one another, Victor Books, Wheaton, IL.

Heschel, A., 1975, The prophets, vol. 2, Harper \& Row, New York, NY.

Hughes, S., 1981, A friend in need, Kingsway Publishers, Eastbourne.

Jackson, W.C., 1985, Spiritual dimensions of pastoral care, Westminster Press, Philadelphia, PA.

Küng, H., 1967, The church, Search Press, London.

Lartey, E.Y., 1997, In living colour, an intercultural approach to pastoral care and counselling, Wellington House, London.

Lohfink, G., 1982, Jesus and community, Paulist Press, New York, NY.

McGrath, A.E., 2008, Theology: The basic readings, Blackwell Publishing, New York NY.

Msomi, V.V., 1993, 'The future of pastoral work in South Africa', In Praktiese Teologie in Suid Afrika 8(2), 73-82.

Oglesby, W.B., 1986, 'Lay pastoral care revisited', Journal of Pastoral Care 27, 307-326.

Pannenburg, W., 1975, Faith and reality, Search Press, London.

Parrat, J., 2004, An introduction to Third World theologies today, Cambridge University Press, Cambridge.

Patton, J., 1993, Pastoral care in context, Westminster/John Knox Press, Louisville, KY. Pieterse, H., 2001, Preaching in a context of poverty, Unisa, Pretoria.

Pope, R., 2006, The intentional church, Moody Publishers, Chicago, IL.

Poser, K., 1987, Called to be neighbours, WCC Publishers, Geneva.

Schaeffler, R., 1994, Therefore, we remember, Liturgical Press, Collegeville, MN.

Solomon, C., 1992, Handbook to acceptance, Tyndale House Publishers, Wheaton, IL.

Stokes, P.J., 1990, Grace under pressure, Navpress, Colorado Springs, CO.

Tillich, P., 2000, The courage to be, Yale University Press, New Haven, CT.

Tracy, D., 1983, 'The foundations of practical theology', in D.S. Browning (ed.), Practical theology: The emerging field in theology, church, and world, p. 76, Harper and Brothers, New York, NY.

Watson, D., 1981, Discipleship, Hodder and Stoughton, London.

White, E.G., 1940, The desire of ages, Pacific Press Publishing Association, Mountain View, CA.

Wise, C.A., 1989, The meaning of pastoral car, Meyer-Stone, Bloomington, IN. 